\title{
UNDERSTANDING TRADITIONALIST OPPOSITION TO MODERNIZATION: NARRATIVE PRODUCTION IN A NORWEGIAN MOUNTAIN CONFLICT
}

by

Tor A. Benjaminsen and Hanne Svarstad

BENJAMINSEN, T.A. and SVARSTAD, H. (2008): 'Understanding traditionalist opposition to modernization: narrative production in a Norwegian mountain conflict', Geogr. Ann. B 90 (1): 49-62.

ABSTRACT. In Gausdal, a mountainous community in southern Norway, a conflict involving dogsledding has dominated local politics during the past two decades. In order to understand local protests against this activity, in this article we apply discourse analysis within the evolving approach of political ecology. In this way, we also aim at contributing to the emerging trend of bringing political ecology "home". To many people, dogsledding appears as an environmentally friendly outdoor recreation activity as well as a type of adventure tourism that may provide new income opportunities to marginal agricultural communities. Hence, at a first glance, the protests against this activity may be puzzling. Looking for explanations for these protests, this empirical study demonstrates how the opposition to dogsledding may be understood as grounded in four elements of a narrative: (1) environmental values are threatened; (2) traditional economic activities are threatened; (3) outsiders take over the mountain; and (4) local people are powerless. Furthermore, we argue that the narrative is part of what we see as a broader Norwegian "rural traditionalist discourse". This discourse is related to a continued marginalization of rural communities caused by increasing pressure on agriculture to improve its efficiency as well as an "environmentalization" of rural affairs. Thus, the empirical study shows how opposition to dogsledding in a local community is articulated as a narrative that fits into a more general pattern of opposition to rural modernization in Norway as well as internationally.

Key words: discourses, narratives, political ecology, rural change, modernization, environmentalization, Norway.

\section{Introduction}

If you are looking for a memorable adventure holiday, dogsledding is the right thing to do. Experience one of the most beautiful areas of true wilderness remaining.

This quote is from one of the Norwegian websites advertising dogsledding safaris for foreign tourists. Even though the Norwegian polar explorer Roald Amundsen used dogsleds when he beat Robert F. Scott to the South Pole in 1911, dogsledding is relatively new as a recreational activity in Norway. It usually involves a pack of six dogs or more, a sled and a musher (driver). ${ }^{1}$
In this article, we focus on a conflict around dogsledding in the mountain area called Gausdal Vestfjell in south-central Norway (Fig. 1). The activity may be seen as a pollution-free and environmentally friendly way of experiencing wilderness far from the fracas of modern life. In the late 1970s and early 1980 s, young people with a largely urban, middleclass and academic background or values and who had taken up dogsledding started to move to Gausdal. Their main motivation was to carry out dogsledding as an outdoor recreation activity and to some degree as a sport. By moving to a rural area such as Gausdal, they also contributed to turning around the trend of rural outmigration and to the development of alternative sources of income from tourism. This occurred in a community dependent on marginal agriculture and confronted with demands for increasingly higher efficiency and reductions in subsidies. From this perspective, one would think that dogsledding would be regarded locally as a positive contribution to the community. Nevertheless, since the mid-1980s, it has been the focus of a heated local debate dominating local politics (Benjaminsen and Gundersen 2005). We see this as a result of dogsledding being perceived by some local actors as an activity symbolising an external threat of modernization ${ }^{2}$ and 'detraditionalization' (sensu Beck et al. 1994).

In this study, we have chosen to carry out an indepth analysis of the opposition to dogsledding, rather than presenting extensive and more superficial descriptions of the positions of all the actors in the conflict. As outsiders to the conflict, we find the opposition to constitute the most challenging task to understand, and thereby also the most interesting element of the conflict. ${ }^{3}$

The analysis started with an examination of the accounts provided by the opponents of dogsledding in the area, and we found that these accounts contained a construction consisting of four core ele- 
ments. During the analysis, we sought a deeper understanding by comparing these empirical findings to literature from other studies of responses to contemporary rural changes in Norway. We found clear parallels between the four elements of the construction concerning the particular conflict and a way of thinking that may often be found in Norwegian rural disputes, and that we, using a discourse perspective, call a "rural traditionalist discourse". First, what may be called an 'environmentalization' of rural landscapes (sensu Milbourne 1997) is seen as leading to restrictions on local and traditional use of natural resources. The argument from rural traditionalists is that local and traditional use represents a more genuine environmentalism than that of the modern environmentalists. Second, the traditionalist rural discourse expresses strong protests against the ongoing pressure towards the modernization of rural economic activities. This pressure is felt as a heavy burden in rural communities. It consists of demands for increased efficiency as well as for a diversification of economic activities. It is generally felt that this pressure leads to a marginalization of traditional use and production methods. Third, external actors (regional and central authorities, environmentalists, urbanites moving to rural areas) are perceived as representatives of the on-going changes towards environmentalization and economic modernization. Fourth, there is a perceived political marginalization of rural populations and traditional values. We argue that these four factors together form a rural traditionalist discourse with a strong standing in Norway. Concomitantly, we conclude the concrete construction by the dogsledding opposition in Gausdal to constitute what we conceptualize as a narrative connected to the broader discourse.

The article has three aims. First, we have an empirical aim of understanding the specific case of a severe and long-lasting local rural conflict. Second, we want to contribute to the elaboration of discourse analysis within the evolving framework of political ecology. Third, we seek to apply political ecology in a Scandinavian context.

Current political ecology usually has a focus on power relations in land and environmental management at various geographical levels, from the local via the national to the global, and the interlinkages between these levels. This approach has today 'become firmly established as a dominant field of human-environmental research in geography' replacing its predecessor cultural ecology (Walker 2005, p. 73). There is a particular interest in the ways that power relations are reinforced or contested in environmental discourses, which are maintained by powerful actors and by environmental movements (Stott and Sullivan 2000; Martinez-Alier 2002). In reviewing the frontiers of political ecology, Peet and Watts (1996) also argue that discursive approaches to the analysis of environment and development are central to this emerging discipline. This area of political ecology includes research in the sociology of science and knowledge, the history of institutions, policy on environment and development, and the globalization of environmental discourses. However, environmental struggles and conflicts are both about battles over meanings and resources (Brosius 1999). Hence, analyses of struggles over meanings and over material assets are inseparable.

With the study located in the North, the paper is in line with an emerging trend of bringing political ecology "home" (Wainwright 2005). Until recently, political ecology was seen as a particular perspective on environmental issues that is uniquely relevant in a development context due to the history of colonialization and the widespread poverty in the Third World (Bryant and Bailey 1997). However, during the past few years 'political ecologists working in many other parts of the world are now heading north, or simply going global' (Schroeder et al. 2006, pp. 163-164). This trend has resulted in special issues of geography journals on political ecology in the First World (Environment and Planning A; see McCarthy 2005) and on political ecology in North America (Geoforum; see Schroeder et al. 2006). In the Geoforum issue, Robbins (2006) for instance, provides, a topically related study to ours in carrying out a narrative analysis of moose management in Yellowstone. In this study, our own previous experience with studying narratives and discourses in Africa within a political ecology framework (Adger et al. 2001; Hongslo and Benjaminsen 2002; Svarstad 2004; Benjaminsen et al. 2006), and the emerging trend of bringing political ecology home, has inspired us to provide a political ecology analysis of an environmental conflict in a rural community in Norway.

\section{Epistemology and methodology}

We argue that there is a useful conceptual distinction to be made between the two interconnected concepts of discourse and narrative. In a broad sense, we see both discourse and narrative as shared ways of understanding and presenting a so- 
cial phenomenon. Furthermore, the application of both concepts implies the recognition of a certain structure and stability of specific social constructs. Thus, many social scientists apply discourse and narrative more or less interchangeably. However, we believe it is important to distinguish between social constructions about specific cases on the one hand (narratives), and frameworks for construction of broader and more abstract phenomena on the other (discourses). We see discourse as the wider concept implying the ontology of a social construction of a topic in a general sense. ${ }^{4}$ Thus, the discourse in focus provides a framework that we believe many rural people often use in order to interpret different aspects of their situation.

Our discourse analysis is elaborated from various contributions to social science-based discourse analysis, with the seminal work of Michel Foucault constituting a central source of inspiration. Foucault framed major discourses in various historical contexts on, for instance, practices of punishment and imprisonment (Foucault 1979) and the establishment of medical treatments of madness (Foucault 1988). However, in line with criticism often raised against Foucault's 'actorless discourses' (e.g. Fox 1998), we believe it is important to stress that we see discourses as products created by actors. On the other hand, discourses also provide structures that actors apply in their interpretation of social matters.

Within the environmental field, discourse analysis has been applied to characterize pervading and received wisdom about the evolution of environmental crises and their social construction in the study of ozone layer depletion (Litfin 1994), acid rain (Hajer 1995), and to classify the main environmental discourses (Dryzek 1997) to mention but a few early and distinctive contributions. In line with Mühlhäusler and Peace (2006, p. 458), we deal with discourses that provide 'specific ways of talking about particular environments and their futures'. Furthermore, in accordance with Dryzek, we find discourses powerful in the way they delimit options for interpretation of information. This implies that discourses facilitate action, while at the same time they can blind their proponents from seeing alternative interpretations and actions. Our approach is similar to that of Adger et al. (2001), who identified leading discourses from inductive examinations of four topics within environment and development and then compared these discourses to each other.

The narrative concept that we use is first of all inspired by Roe (1991, 1995, 1999), who brought nar- rative analysis into the field of environment and development. Roe defines narratives as stories with a beginning, middle and end, or when cast in the form of an argument, with premises and conclusions. We find Roe's narrative perspective in this field useful when applied to specific case studies and in combination with examinations of the phenomena of more general production of meaning that we distinguish as discourses. ${ }^{5}$ It is important to stress that our concept of narrative implies that accounts of specific cases are framed by the narrative producers within a wider discourse. Thus, we do not consider all stories and accounts by participants or observers in a specific conflict as narratives.

Furthermore, our methodology is inspired by grounded theory with an open-ended coding and category building (Glaser and Strauss 1967; Strauss and Corbin 1990; Mjøset 2005, 2006). This implies that we believe it is important to try to understand the discourses and narratives on their own premises. At the same time, we believe it is useful and important to proceed to a comparison of identified discourses with each other in order to point to similarities and differences, and thereby elaborate typologies of discourses. Our interest lies in the contents of discourses in contrast to much of the more form-oriented linguistic approaches. Furthermore, we believe it is useful to begin studies with a focus on a narrative on a delimited issue, and from there move on to more abstract levels through comparisons with related social constructions about similar albeit more and more different phenomena. We start out by examining closely the case of the opposition to dogsledding, and we argue that accounts emerging from this opposition are produced as a narrative of a broader Norwegian rural traditionalist discourse.

The case study is based on qualitative interviews carried out in 2002 and 2003 with about thirty of the most central actors in the conflict in Gausdal. Thus, our presentation of a narrative is based on the perceptions of the issue that we found among the opponents at that particular time. ${ }^{6}$ The interviews were recorded and transcribed. As a background to the conflict, we have also read through private and public records and newspaper articles from the past twenty years. The identification of the rural traditionalist discourse in Norway is based on comparison of the case study with literature from other studies in Norway.

\section{The conflict}

The conflict is about whether or not one should allow dogsledding in Gausdal State Commons ${ }^{7}$ in 

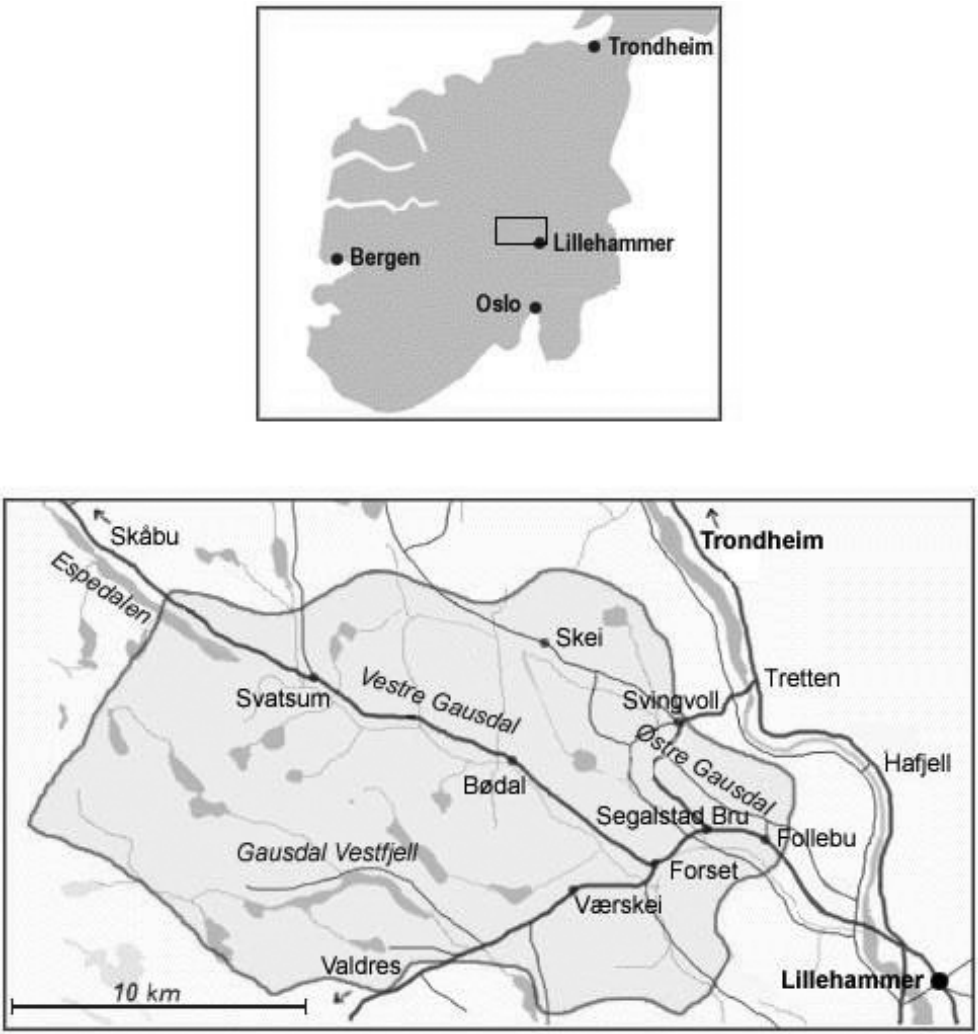

Fig. 1. Map of Gausdal.

south-central Norway, and if and how one should regulate this winter activity. The Commons lies in the mountain area called Gausdal Vestfjell (or Vestfjellet) covering an area of 58900 hectares, which again covers half the area of Gausdal municipality (Fig. 1). The altitude in Vestfjellet ranges from 600 metres above sea-level to the highest peak at 1554 $\mathrm{m}$. This mountainous area is generally covered with snow from November to May. From mid-June livestock is released on summer pastures in the mountains. Most farmers in Gausdal either do sheep or dairy farming. The population size in the municipality has fluctuated between about 5000 and 7000 since the 1830s, with peaks reached in the 1860s and 1950s (Gausdal Kommune 2005). Farms in Gausdal have use rights in the Commons. This is an old right, which includes the right to pastures, mountain farming, ${ }^{8}$ hunting and fishing, and the extraction of wood and timber for own consumption (Bye 1997). In Gausdal State Commons, the parastatal company Statskog is the landlord, while a Commons Board, elected among the local farmers, manages the forest, and a Mountain Board, elected by the Municipal Council, is responsible for the management of other resources in the commons. However, dogsledding is a new form of outdoor activity, to which the old Commons legislation does not relate. To freely carry out their activity, mushers refer to the Right to Roam (Allemannsretten), which is more recently confirmed by the Outdoor Recreation Act of 1996.

In the 1970s, a few active mushers moved to Gausdal to train their dogs in Vestfjellet and, during the 1980s, the number of mushers living in the local community increased. From the mid-1980s, opposition against this activity emerged and gained in importance over the next few years. The main argument against dogsledding in Vestfjellet has been that it frightens the moose (Alces alces) in the area and thereby decreases the resource base for the annual moose hunt. In the late 1980s, the municipality set up a committee to look into the issue. Since the track was situated away from the main migration route of the moose, the argument was that if the mushers could stick to this track, dogsledding would have less of an impact on the moose population. Some opponents still wanted dogsledding to be completely banned from Vestfjellet, while oth- 
ers could accept it if it was confined to the track setup. As a compromise solution, the committee proposed a fixed track to be followed by the mushers. There was also disagreement concerning how comprehensive the whole activity was. While there were more than twenty mushers in Gausdal in the 1980 s, currently this number is down to only four or five. Nevertheless, after 2000 the conflict is still very "hot" in the community.

We identify three main actors involved in the conflict: the mushers, the opponents, and the municipal and state administration. In addition, the wildlife researchers, who in the 1980s carried out studies of the moose population in Vestfjellet, may also indirectly be seen as an actor, because their research plays a central role in the debate. Bits and pieces of this research are used by the opponents, but without the wildlife researchers themselves participating directly in the debate. The active opponents are relatively few, but they are very active in return. The local newspaper GudbrandsdølenDagningen (GD), based in Lillehammer, is the most important arena where the conflict has been played out. $G D$ has had an extensive coverage of the issue since the 1980s.

\section{The dogsledding opposition narrative}

In the following, we present the findings of our empirical study of the opposition against dogsledding in Gausdal. The thrust of the narrative is as follows.

Gausdal Vestfjell is a unique mountain area with long traditions of sustainable use through mountain farming, fishing, and moose and small game hunting. However, traditional use is today threatened by dogsledding, which is taking over the mountain and which is an activity conducted by outsiders who do not respect traditions in the local community. The most serious consequence of dogsledding is that it scares away the moose from the area. Whereas the mushers are getting their will, local people are powerless.

This follows the narrative form of a beginning (here with a situation without problems), a middle (outsiders have come in and started dogsledding), and an end (threats and negative consequences are emerging, and local people do not have the power to do anything about it). The arguments embedded in the narrative may be divided into these four main elements:
1. environmental values are threatened;

2. traditional economic activities are threatened;

3 . outsiders take over the mountain;

4. local people are powerless.

The four elements are closely connected, while we deal with them one by one due to the analytical aim of the paper. ${ }^{9}$ Each section begins with the presentation of the primary findings based on the interviews.

\section{Environmental values are threatened}

The mushers perceive themselves as people enjoying wilderness in an environmentally friendly way. They seek outdoor experiences which do not need any investment in infrastructures that transform the landscape such as downhill skiing resorts, and dogsledding does not cause any pollution or noise ${ }^{10}$ such as off-road motorized vehicles. On the other hand, the opponents perceive dogsledding as an environmental disturbance, and in contrast to the traditional economic activities in Gausdal Vestfjell, which they see as genuinely environmentally sustainable. Traditional use entails activities such as mountain farming and moose hunting.

The opponents are very attached to the landscape and traditional use of Vestfjellet. During the interviews, several of them started by talking about their upbringing on a farm, the summers on the mountain farms in their childhoods, and about being brought up with certain values that they still want to defend. One of them, for instance, said: 'I learned about mountains and mountain farming even before I could read or write.'

The opponents emphasize the importance of leaving these mountains undisturbed during winter in accordance with the traditions in which Vestfjellet has been used extensively for summer farming and natural resources use during summer, while during winter the area has hardly been visited by people. As the author of a local history book wrote, Vestfjellet has been lying there virtually untouched during winter with its wide-open spaces (Bye 1997). Mushers interviewed complain that Gausdal Vestfjell is perceived by the community almost as a holy mountain where 'there should not be any activities during winter'.

Gausdal municipality has designated the northern mountain, the area known as Skei, as the local area for development of tourism, in contrast to the western mountain (Vestfjellet). Skei has Norway's oldest mountain hotel, which was built more than 
a hundred years ago, and today the area resembles a resort in the Alps, with its supermarket, ski-lifts, campsite, hotels, golf-course and large-scale building of private cabins where urban residents spend their weekends and holidays. It is an expressed aim in municipal planning documents that Vestfjellet be protected against this type of tourism development. It is therefore generally acknowledged and accepted locally that Skei is designated for tourism and Vestfjellet for local and traditional use. Hence, according to the opponents of dogsledding in Vestfjellet, the mushers are on the wrong mountain. The way the mushers use the mountain is not seen as traditional, but rather as a form of tourism or recreational use which should take place at Skei. But moving to Skei is not interesting for the mushers, because it is exactly the open undeveloped "wilderness" in Vestfjellet that attracts them to this place. In addition, the companies involved in tourism at Skei would not welcome the mushers, and their arrival there would have created a host of other use conflicts, with, for instance, deterioration of the tracks for cross-country skiing.

A main argument of the opponents is that dogsledding is harmful to the local moose population. Arguing that dogsledding frightens the moose, one opponent said:

If left in peace, the moose will go where there is food. Number one is food, but it is also important that it does not feel threatened. Then it will flee from the area. Just like people, it will run away if it feels threatened. ${ }^{11}$

Another interviewee sees the Gausdal moose in a wider environmental perspective:

This is a migration route and a winter pasture, which is unique ... and we have a great responsibility to take care of this area.

A third opponent agrees, saying:

I am very critical to dogsledding in the most important moose biotopes in Oppland county. You must remember that the moose population in Vestfjellet is unique.

The opponents also point out that while the population of moose in winter in Vestfjellet has decreased, it has increased further north in a valley called $\mathrm{Mu}-$ rudalen. While there is forest encroachment ${ }^{12}$ in Vestfjellet, Murudalen is said to be overstocked leading to a degradation of the pine forest. In fact, the increased population of moose in Murudalen during winter is a much-discussed topic in the local newspaper. Recently, hunting of moose during winter has been introduced in Murudalen, including the hunting of pregnant cows, and this has spurred a hot local debate. In Gausdal, the opponents argue that dogsledding in Vestfjellet frightens the moose and makes it continue the migration to the overstocked Murudalen.

Besides the concern for the environment of the moose, opponents argue that dogsledding also has other negative impacts on the environment. They claim that the activity frightens other wildlife species, such as the polar fox, the grouse and other bird species. In addition, they argue that mushers leave garbage when they spend nights in the communal cabins available in the Commons. Furthermore, mushers from abroad visit Gausdal Vestfjell once in a while, and the opponents believe that this leads to increased risks of infection of animal diseases such as foot and mouth disease.

\section{Traditional economic activities are threatened}

Mountain farming, hunting and fishing have historically played a relatively major economic role for people in Gausdal. One of our informants estimated, for instance, that until the 1950s the farms in the western part of Gausdal received up to 20 per cent of their livelihoods from the Commons. At the same time, the mountain has been more or less free from human use during winter.

Local people in Gausdal claim that traditional economic activities, such as mountain farming, are difficult to sustain today due to economic and political factors at the national and international level. At the same time, the opponents to dogsledding have observed that outsiders have moved to Gausdal and introduced an activity they do not feel belongs there. One opponent said: 'I'm afraid that if this development continues, the traditional use of the mountains will be lost.'

On the other hand, some of the mushers in Gausdal have to a certain extent established income-generating activities based on dogsledding. Local mushers sometimes take tourists out on trips against payment. This was, for instance, a popular activity during the Winter Olympics in Lillehammer in 1994. In the mid-1980s, one of the mushers also proposed to build a camp and a Scandinavian dogsledding centre in Gausdal Vestfjell.

The negative impact on the moose population is 
not only seen as an environmental threat, but also a threat to moose hunting, which in the local community is considered as a traditional economic activity of great importance. In the interviews, the opponents refer to the pitfalls from the Iron $\mathrm{Age}^{13}$ on the old migration routes for moose, to stress the long tradition of the moose hunt. The opponents also emphasize the economic importance of current moose hunting in Gausdal. Just as an example of the economic value of the moose hunt, about 120 moose are shot every year in Gausdal State Commons. Each moose would on avereage represent $150 \mathrm{~kg}$ of meat, while the price per $\mathrm{kg}$ would be around $80 \mathrm{NOK}$ (c. 10 euros). This means that the meat from the Commons would be worth around 1.440.000 NOK. Sixty per cent of the hunting licences are sold to local hunters and 40 per cent (for a higher price) to hunters from outside Gausdal. In addition to the direct economic value of the moose, there are also indirect economic benefits to the local community caused by this activity.

In addition to the economic value, a study by Aagedal (1999) shows that moose hunting in forest communities of south-eastern Norway may play a central role as a bearer of local tradition and identity. However, despite perceptions of moose hunting as a "traditional" activity, the annual moose hunt in September/October is a relatively new phenomenon in Norway. Its emergence is a result of a tremendous increase in the population of moose since the 1950s. In 1899, only 843 moose were shot in Norway, while the number was around 35,000 in 1999 (Aagedal 1999). New wildlife management techniques introduced in 1967 would be the main reason for this increase (Rønningen et al. 2001). ${ }^{14}$

Despite the moose hunt at the current scale being a new phenomenon, it is perceived as a traditional activity that links the hunters closer to the land and its historical use. There are few big landowners in Norway, but there are many who own a relatively small piece of land and forest. Hence, forest owners have to pool their resources and cooperate in order to organize an efficient hunt. Hunting in Norway is therefore not associated with an upper class or an aristocracy, as, for instance, in Great Britain. It is a popular activity, which serves to maintain and reproduce the identity of the local community and its links to the land. According to Aagedal (1999), the moose binds people together and makes it more meaningful to live in rural areas.

The opposition to dogsledding in Gausdal has also a gendered dimension. With one exception, all the most active opponents are men. Several of the dogsledding opponents participate themselves in hunting. ${ }^{15}$ Skogen and Krange (2003, p. 316) have studied hunters in south-eastern Norway, and their observations are relevant also to our case:

In several respects they keep up a traditional way of living that has been typical for men in rural areas, which entails largely manual work and a somewhat rough contact with nature. They are firmly rooted in what we might term a production-oriented culture; cultural forms that are typical of workers and farmers, comprising high valuation of practical work, technical ingenuity and masculine toughness, and scepticism towards academic knowledge and intellectual pursuits.

With respect to livelihood and class aspects, the opponents in Gausdal fit well the description in the above quote, while the mushers tend to have higher education. There is also an age dimension to the conflict. We have not heard of any active opponents in the valley today who are below 50 years old. The mushers, on the other hand, started to move into Gausdal at relatively young ages. Thus, the opposition may fit into a broader picture in rural areas of Norway where the older generations find it particularly hard to change their livelihood and way of life in accordance with the pressures from modernization.

\section{Outsiders take over the mountain}

An important aspect of the opposition to dogsledding is that the activity is conducted by people who are new in the community. The fact that few of the mushers originally come from Gausdal is stressed by several of the opponents. On the question of whether the mushers are local people, one answered: 'No, no, no. None of them are from this area. Well, there are a few, but at a very, very small scale.'

Almost all the mushers have moved to Gausdal from other places in Norway. Most of them have rented or bought properties (small farms, cabins or houses) in the western part of Gausdal, which is closest to Vestfjellet. Thus, the mushers are seen as outsiders who do not 'belong' in the community in the sense that they have not grown up in the valley or do not have relatives there. Furthermore, the mushers are also different from their active opponents as well as from a large part of the local people in the valley by generally having an academic ed- 
ucation, and none of the mushers make their living from activities directly related to agriculture. Hence, the mushers are people with middle-class values. They come to use the mountain to carry out their modern leisure activity in contrast to local people's more established uses of the area for extractive purposes. Moreover, the mushers do not leave after their holidays like other tourists - they have moved permanently into the municipality.

The mushers themselves confirm our interpretation of this element of the narrative from their opponents. One of the mushers says:

Gausdal is like a dead-end and quite a closed community. Many people who move to Gausdal experience that it is a difficult place to get to know the locals and that there are a number of social codes that it takes a few years before you manage to understand.

Furthermore, the mushers link the scepticism towards themselves with scepticism towards immigrants in general. One puts it this way: 'We become a threat to how things have always been done. It is the same with foreign immigrants. They are also easily stigmatized'. Thus, the mushers think that local opposition to a camp for asylum seekers in Gausdal and the opposition to their own activities have the same roots and causes. In addition, between 1994 and 2000, one of the mushers ran a home for youths mainly from Oslo with drug problems. Dogsledding was used as an important element of rehabilitation. However, some of the youngsters created problems locally by, for instance, stealing cars. This combination contributed to strengthen the feeling among the opponents of mushers as strangers who represent threats and negative impacts on the community.

\section{Local people are powerless}

The fourth and final element in the narrative of the opponents to dogsledding is the perception that the "true locals" have lost power. One interviewee claims that in Gausdal it is the outsiders who have moved to the community that decide. 'We locals are marginalized', he says, and he continues:

It is a fact that we socially and politically have had a new group of people established in the community that do as they like, do not follow the rules, and disregard the interests of farming and hunting.
Some hunters argued that wildlife researchers have clearly documented the negative impacts of dogsledding on wildlife, and especially on the moose population, but they have not been heard. 'We have enough facts to give us an answer to what is going on in Gausdal Vestfjell', one says, and he adds:

But the administration neglects the information that is available. In fact, politicians have made decisions based on flawed and incorrect information. I think that the information presented should be correct and that it should build on investigations carried out by the specialists.

The opponents of dogsledding are concerned about farming interests being continuously marginalized. They see the municipal administration, the Mountain Board and Statskog as their main opponents. The mushers are also criticized, but the strongest criticism is directed towards the local and regional bureaucracy, which is seen as taking the side of the mushers. The bureaucracy is accused of not listening to reasonable arguments, not considering available documentation, and for stigmatizing and ridiculing the opponents. They represent a "comradeship" that includes some of the mushers. One interviewee said: "We call it comradeship, but in the south $^{16}$ they call it corruption.' For instance, the mushers work closely with the Mountain Board, they claim. In this way, the opponents do not manage to present what they see as "the facts". The local bureaucracy is allegedly more concerned about facilitating local business opportunities than about conserving nature and its traditional uses.

\section{Linking the local oppostion to a Norwegian discourse and a global discourse type}

According to Lyotard (1997), we should be facing a transition to a postmodern condition of knowledge in which the 'grand narratives' of the modern area lose their importance. Such grand (or meta-) narratives (translated from metarécits in French) are claimed to represent a general and final truth. In a postmodern absence of grand narratives, Lyotard sees small narratives at work everywhere. The contents of these narratives are negotiated locally. However, contrary to Lyotard, we argue that studies of local conflicts can reveal that there are underlying patterns in local constructions that are widely shared at a national as well as at a global scale. This does not mean that we do not see local and case- 
based variations. It does, however, imply that we recognize that discourses today are far-reaching and powerful.

Thus, in the specific case of the conflict on dogsledding in Gausdal, we argue that the accounts of the opponents constitute a narrative belonging to what we call a rural traditionalist discourse in Norway. Furthermore, this discourse is again linked to a traditionalist discourse type with global relevance.

In the following, we look at each of the four narrative elements and argue that they have a broad relevance beyond the case itself. First, opponents of dogsledding express a strong attachment to the landscape and traditional uses of Vestfjellet, and they portray dogsledding as an activity with negative environmental impacts. We believe this to be an example of the application of an argument often used constituting an element of a rural traditionalist discourse. Here, external pressures towards the 'environmentalization' (Milbourne 1997), of specific areas and natural resources are met with traditionalist arguments, implying that traditional uses of landscapes are presented as a more genuine type of environmentalism than the one brought in by external actors. These external actors represent modernization by introducing environmental preservation or leisure activities presented as environmentally friendly wilderness experiences. ${ }^{17}$

Local hunters have traditionally dominated local decision-making on the management of forests and mountains. Gundersen (1991) argues that this hegemony has, since the arrival of sustainable development on the political agenda in the 1980s, been challenged by an environmentalization of local politics and management. This has led to local use becoming increasingly restricted due to pressure first of all from urban-based environmentalists. In rural Norway, this process is perceived as a form of centralization of power from local institutions to the institutions of the state (Daugstad et al. 2000; Aas 2003). Environmentalization has taken place through various processes over the past few years such as the large increase in designations of new protected areas in Norway (Daugstad et al. 2006; Vistad et al. 2006) and through the growth of carnivore populations (Svarstad 2003).

At present, environmentalism holds a strong moral position in Norway as well as in the rest of the world. This makes arguments for environmental sustainability and environmental friendliness almost indisputable. We believe that the case of the opposition to dogsledding in Gausdal points to a strategy of narrative construction that may be widespread, in which traditionalist arguments are presented as environmental arguments. Moreover, this "traditionalist environmentalism" is portrayed even as a more genuine environmental position than that of people who bring in modernity in the form of conservation schemes or, in this case, as a modern leisure activity presented as an environmentally friendly wilderness experience.

Second, dogsledding is seen to represent a threat to the traditional economic use of Vestfjellet, traditional livelihoods and way of life. Here, we find dogsledding to be interpreted in line with a widespread type of opposition to pressures for modernization of rural economic activities. The economic challenges to rural communities are, on the one hand, constituted by a marginalization of traditional economic activities. Agriculture, which is still the economic foundation for rural settlements in Norway, goes through a continous process of change towards higher efficiency. It is becoming difficult to maintain a reasonable income from farming, due to declining subsidies and policymaking dominated by urban values. The government's reductions of subsidies and introduction of new restrictions are partly results of the adoption of EU and WTO rules (Rønningen et al. 2001; Almås 2002; Rønningen 2003).

In addition, there are pressures towards diversification of the rural economies and encouragement of farmers and others to establish new commercial activities. Tourism is central here, and during the past few years there has been a focus on a growing market for various specialist wilderness experiences. This entails activities such as white water rafting, caving and moose safaris (Dervo et al. 2005). Dogsledding safaris fit well into this picture.

While some rural inhabitants meet the economic challenges with attempts to change into new economic activities, others are more hesitant about such changes. In a study of types of farmers and their adaptations in Trøndelag County in central Norway, Vik (2005) identified six categories of farmers (the professional farmer, the local patriot, the entrepreneur, the ecological farmer, the grumpy farmer, and the tired farmer). These different types of farmers are to varying degrees able to adapt to the new challenges. The perspectives of the grumpy and the tired farmers are in line with the dogsledding opposition narrative's outspoken resistance to the pressure to change from traditional farming to increased efficiency and diversification. We should also add that in Gausdal the opponents of dogsled- 
ding are all senior citizens and adaptations to new challenges in rural areas seem to be most difficult to handle by the older generation.

Third, an important element of the narrative is that the mushers themselves do not originally come from Gausdal, but they have moved to the valley from other parts of Norway. Furthermore, some local people feel that this new and modern leisure activity represents an encroachment on the mountain. They see Vestfjellet as an area that should be exclusively used for traditional resource extraction activities. The narrative provides the entrance to see the contours of two types of oppositions towards outsiders in the rural traditionalist discourse. On the one hand, there is scepticism towards "strangers". On the other hand, there is a reaction against powerful government officials whose decisions impact upon local livelihoods and way of life.

Bauman (1991, pp. 59-60) provides an explanation of negative reactions to strangers, who represent more than just the unknown. The stranger is someone who comes today and stays tomorrow:

The stranger comes into the life-world and settles there ... [and] unlike other 'straightforward' enemies, he is not kept at a secure distance .... The stranger undermines the spatial ordering of the world - the fought-after co-ordination between moral and topographical closeness, the staying together of friends and the remoteness of enemies .... The stranger who refuses to go away gradually transforms his temporary abode into a home territory.

Furthermore, Fischer and Forester (1993) state that in rural areas in Great Britain there is 'an urban encroachment' that threatens the rural lifestyle and identity. A Norwegian parallel is the expression 'rurbanization' (Hompland 1984; Villa 2000). This implies an urbanization of lifestyle, economic activities, cultural expressions and consumption without the formation of urban areas. Through this influence, the old rural social forms and networks tend to disintegrate and as a result some "natives" will attempt to establish, strengthen or change boundaries. Such boundaries are established to define "who is in and who is out of relevant peer groups and networks of prestige or authority' (Jasanoff 1990, p. 14).

Fourth, the "true locals" see themselves as marginalized politically. This marginalization is caused by urban values, interests and power dominating local affairs and conflicting with the local community.
Resistance to outsiders among dogsledding opponents in Gausdal resemble rural perceptions of the reappearance of large carnivores in Norway. In particular, sheep farming communities are concerned about the increases during the past few years particularly of wolves, but also of bears and wolverines. Many rural inhabitants feel that traditional use of outfields is threatened. They relate this to central decision-making in Norway, and they tend to see themselves as powerless victims of decisions made by storsamfunnet (society at large) (Skogen and Haaland 2001; Skogen and Krange 2003; Skogen et al. 2003; Svarstad 2003). Carnivore opponents often refer to an alliance of enemies of rural and farming interests consisting of urban carnivore romantics, environmental authorities, researchers and the Oslo press, including the state-run Norwegian Broadcasting Cooperation (NRK).

Similarly, the establishments of new protected areas have also been met with perceptions that storsamfunnet take over the control and make decisions contrary to the interests of rural inhabitants. For instance, Lesja Municipality in Oppland County was subject to an article in a farmers' magazine with the following headline (translated from Norwegian): "Lesja may lose the right to rule on $80 \%$ of the areas: The community has managed [the natural resources] - [but] storsamfunnet will rule" (Bondebladet, 3 September 1997). Skogen and Krange (2003, p. 310) observe a paradox that ordinary people living in cities may be seen as part of the powerful storsamfunnet, while not even the elites in rural areas seem to be included. In the case of the opposition to dogsledding in Gausdal, however, the mushers are portrayed as powerful outsiders, but they do actually live in the municipality.

We believe that the rural traditionalist discourse has many parallels in other countries and at a global level. In a study of the political ecology of global environmental discourses, Adger et al. (2001) identified a traditionalist discourse (although labelled "populist") as one of two dominating global discourses on each of the issues of deforestation, desertification, biodiversity use and climate change. Global capitalism is, in this discourse, seen as the cause of environmental problems, and local resource users as the victims of these problems. Outside actors are seen as the villains and local people are heroes who are in possession of valuable knowledge, and whose practices are presented as sustainable. Svarstad et al. (2008) provide a notion of four ideal types of discourse production often found in conflicts on use and conservation of areas and nat- 
ural resources. ${ }^{18}$ These are a Preservationist ${ }^{19}$ and a Promethean ${ }^{20}$ discourse type as well as a Win-win and a Traditionalist discourse type. The dogsledding opposition narrative is in line with the latter.

Furthermore, in development studies, core elements of traditionalist discourses may be found in the dependency school that reached its peak in the 1970 s and early 1980 s criticizing foreign or outside economic interventions in poor countries and regions and advocating self-reliance. ${ }^{21}$ Moreover, since the early 1990 s, several contributions from poststructuralist geographers and other scholars are based on similar ideas (e.g. Escobar 1995; Peet and Watts 1996; Broch-Due and Schroeder 2000). Clear parallels may also be drawn to the radical Localization School of the anti-globalization movement, which, within this movement, is in opposition to the Fair Trade School (Buckman 2004). The core idea of the Localization School is that local economies should be the centre of economic activity; that economic globalization closely associated with the current dominance of neoliberal thinking has taken power away from local economies and that this power should again be reinstated; and that there should be an increased focus on local economic self-reliance (Buckman 2004, pp. 150-153). A key term in this school is "participatory democracy", and the devolution of power to the local level is seen as the solution to current environmental and economic problems. The main difference with the Fair Trade School is that the Localization School argues that global trade destroys both the environment and local economies.

\section{Conclusion}

In line with current political ecology, we have in this article linked a local narrative about a land-use conflict to wider national and global concerns. Hence we have shown that the dogsledding conflict in Gausdal is more than just a local quarrel. Traditionalist narratives and discourses reflect key grassroot concerns related to ongoing global processes of modernization. Our study illustrates how local reactions to modernization and globalization not only address economic aspects, but also involve issues of identity, power and control over land and natural resources. The findings are contrary to Lyotard's idea of a postmodern condition of knowledge formation, since we have found that the local narrative includes much more than merely a locally produced construction. We also suggest that our attempt to bring political ecology home to Norway and Scandinavia has resulted in a contribution "out" to the epistemology and ontology of global political ecology in terms of conceptual specifications and empirical findings.

\section{Acknowledgements}

We would like to thank all the interviewees in Gausdal for their time and interest in this study. We are also grateful to those who made their personal archives available to us. The Norwegian Research Council provided funding for this project through the 'Changing Landscapes' programme. Finally we are grateful to Frode Gundersen for cooperation on the fieldwork and for useful discussions, to Maria Due-Tønnesen for transcribing the interviews, and to Karoline Daugstad, Rick Rohde, Mats Widgren and three anonymous referees for their comments.

\section{Notes}

1. People who practise dogsledding are often called mushers, which comes from "mush", a command used to urge on dogs that pull a dogsled. This is again probably an alteration of the French marchez! or marchons! (advance!) (Oxford Dictionary Thesaurus and Wordpower Guide 2001). The Norwegian term for musher is hundekjører, which literally means dog driver. Pedersen (1999) and Neumann (2006) provide insights into Norwegian dogsledding milieux in Finnmark and Oslo, respectively.

2. Agricultural modernization is a process often involving specialization, scale enlargement, intensification and industrialization of agricultural production (Ploeg et al. 2000).

3. A competing win-win narrative, which is presented by local bureaucrats, politicians and mushers, argues grosso modo that dogsledding is an environmentally harmless activity, which can bring local income through dogsledding safaris.

4. This is a concept of discourse in line with many or perhaps most social science contributions. In contrast, a linguistic position is to see a discourse as 'a stretch of language that may be longer than one sentence. Thus, text and discourse analysis is about how sentences combine to form texts' (Salkie 1995, p. ix). Furthermore, in everyday language the term "discourse" may be used synonymously with speech or conversation.

5. Roe himself does not distinguish between social constructions at various levels. These constructions are all termed narratives in his vocabulary. The distinction we establish between discourses and narratives is in line with Svarstad (2002) and Fischer (2003).

6. Narratives as well as discourses may be reproduced in a similar fashion during a long period of time, but they may also be subject to substantial changes.

6. The Commons in Norway are old institutions. The first written legislation on Commons is from 1276. From the Middle Ages the kings controlled the Commons. While the king or the state constituted the landlord, local communities still held use rights to natural resources in the commons (Grimstad and Sevatdal 2007).

7. Here we translate setring as mountain farming. A seter is a 
small farm in the mountains for dairy production during summer. Livestock are brought from the permanent farm in the valley to the mountain farm to spend two to three summer months on the rich mountain pastures that are usually found there. This practice of seasonal transhumance is known from many parts of the world (e.g. the Alps, the Himalayas, pastoralism in dryland Africa). The practice of mountain farming has been in decline in Norway since the Second World War (Daugstad 2000).

8. The identification of a clear narrative constitutes a main finding of the empirical study. We must, however, stress that we did observe variations between the constructions of various interviewees. First of all these variations relate to the relative emphasis given to each of the four elements, and all interviewees did not bring up all of the four elements. Furthermore, there were several individual variations. These did not, however, constitute any major deviation from the narrative as we present it here.

9. According to the mushers, dogs bark in the parking lot before they set off, but the activity itself is silent.

10. In relation to the development of a hydro power plant during 1986 to 1989 , detailed studies of the moose and its migration patterns in the area were commissioned to a team of researchers (see Andersen et al. 1984; Andersen and Sæther 1996). We interviewed two of the biologists involved in this research (Reidar Andersen, interviewed 12 April 2002, and Erling Solberg, interviewed 26 June 2003). They both individually concluded that increased hunting is a probable explanation for the decline in moose in Vestfjellet during winter. They were sceptical about the idea that dogsledding could have any serious consequences for the moose population. 'The moose learn fast what is dangerous and not' and 'it easily gets used to things that have a certain regularity', they said. They are also sceptical to the idea that dogs howling at night will scare away the moose. This would imply that the moose are genetically coded to be afraid of the sound of howling, which does not seem to be the case.

12. The Norwegian term is gjengroing, which literally means regrowth.

13. These pitfalls were graves dug out and covered with branches to trap moose. Some of these pitfalls can still be identified.

14. An important element here is that mainly young and unproductive animals are culled and that bulls and cows to a larger extent are spared.

15. On the other hand, dogsledding in Gausdal Vestfjell is also an activity much dominated by men, although this activity is also carried out by some couples.

16. The term used here was Syden, which literally means the South, but it is a common term used for countries with a warm climate and beaches, which are used as holiday destinations for Norwegians (e.g. the Mediterranean countries, the Canary Islands, the Caribbean, Thailand).

17. When dealing with specific environmental conflicts, we believe it is pivotal to understand the various types of environmental constructions involved. Traditionalist environmentalism often provides important insights, and it generates claims that should be subject to natural and interdisciplinary science investigations on equal basis as the claims by modern environmentalism. Unfortunately, this is often not the case. An examination of a major approach to interdisciplinary research on environmental issues shows how an ignorance of traditionalist constructions is embedded in the approach itself (Svarstad et al. 2008).

18. These are Weberian ideal types (Weber 1949) derived from empirical studies. Their apparence in new contexts cannot be assumed, but they can be useful as templates to compare empirical findings of discourse production in new case studies.

19. The Preservationist discourse type concentrates entirely on the aim of conserving species, biotopes and landscapes, and there is little concern for the restrictions that these interventions place on local resource users.

20. The Promethean discurse type challenges the existence or seriousness of environmental issues, and therefore also rejects the necessity of conservation.

21. Concomitantly, there are resemblances between win-win discourses and the development optimism of the Modernization School from the 1960s and 1970s. Win-win discourses also share similarities with current neoliberalism.

\section{Tor A. Benjaminsen}

Department of International Environment and

Development Studies (Noragric)

Norwegian University of Life Sciences

P.O. Box 5003

$N$-1432 As, Norway

E-mail: torbe@umb.no

\section{Hanne Svarstad}

Norwegian Institute for Nature Research (NINA)

Gaustadalléen 21

N-0349 Oslo, Norway

E-mail: hanne.svarstad@nina.no

\section{References}

AAGEDAL, O. (1999): 'Jakta på elgjaktkulturen', in BROTTVEIT, A. and AAGEDAL, O. (eds): Jakta på elgjaktkulturen. Abstrakt forlag, Oslo, pp.13-45.

AAS, Ø. (ed.) (2003): Bruk og forvaltning av nasjonalparker $i$ fjellet. NINA Report 72, Norwegian Institute for Nature Research, Trondheim.

ADGER, W.N., BENJAMINSEN, T.A., BROWN, K. and SVARSTAD, H. (2001): 'Advancing a political ecology of global environmental discourses', Development and Change 32 (4): $681-715$

ALMÅS, R. (2002): Norges landbrukshistorie IV. 1920-2000. Frå bondesamfunn til bioindustri. Det Norske Samlaget, Oslo.

ANDERSEN, R. and SÆTHER, B.E. (1996): Elg i Norge. Biologi, atferd og forvaltning. Teknologisk forlag, Oslo.

ANDERSEN, R., SLÅEN, A. and GRANBERG, P. (1984): Elgregistreringer $i$ Gausdal Vestfjell 1980-1983, $i$ samband med planer for utbygging av Dokka/Etna-vassdragene. Rapport 8, Direktoratet for vilt og ferskvannsfisk, Trondheim.

BAUMAN, Z. (1991): Modernity and Ambivalence. Polity Press, Cambridge.

BECK, U., GIDDENS, A. and LACH, S. (1994): Reflexive Modernization: Politics, Tradition and Aesthetics in the Modern Social Order. Polity Press, Cambridge.

BENJAMINSEN, T.A. and GUNDERSEN, F. (2005): 'Striden om hundekjøring i Gausdal Vestfjell', Tidsskriftet Utmark 6 (1) [WWW document]. URL http://www.utmark.org.

BENJAMINSEN, T.A., ROHDE, R.F., SJAASTAD, E., WISBORG, P. and LEBERT, T. (2006): 'Land reform, range ecology, and carrying capacities in Namaqualand, South Africa', 
Annals of the Association of American Geographers 96 (3): 524-540.

BROCH-DUE, V. and SCHROEDER, R.A. (eds) (2000): Producing Nature and Poverty in Africa. Nordiska Afrikainstitutet, Uppsala.

BROSIUS, J.P. (1999): 'Green dots, pink hearts: displacing politics from the Malayasian rain forest', American Anthropologist 101 (1): 36-57.

BRYANT, R.L. and BAILEY, S. (1997): Third World Political Ecology. Routledge, London.

BUCKMAN, G. (2004): Globalization: Tame it or Scrap it. Mapping the Alternatives of the Anti-globalization Movement.Zed Books, London.

BYE, J. (1997): Vide vidder i vest. Vestfjellet i Gausdal. Thorsrud AS Lokalhistorisk forlag, Lillehammer.

DAUGSTAD, K. (2000): Mellom romantikk og realisme: om seterlandskapet som ideal og realitet. Report 16/99, Centre for Rural Research, Norwegian University of Science and Technology, Trondheim.

DAUGSTAD, K., KALTENBORN, B.P. and VISTAD, O.I. (2000): Vern - planer og prosesser. Identifisering av kunnskapsstatus og -behov. Working Paper 3/00, Centre for Rural Research, Norwegian University of Science and Technology. Trondheim.

DAUGSTAD, K., SVARSTAD, H. and VISTAD, O.I. (2006): 'Community-based nature protection: lessons from Norway', International Journal of Environmental, Cultural, Economic and Social Sustainability 2 (3): 127-136.

DERVO, B., AAS, Ø. and ANDERSEN, O. (2005): Naringsutvikling $i$ utmark: kunnskapstatus og vurdering av FOU-tiltak $i$ et verdikjedeperspektiv. NINA Report 93/05, Norwegian Institute for Nature Research, Trondheim.

DRYZEK, J. (1997): The Politics of the Earth: Environment Discourses. Oxford University Press, Oxford.

ESCOBAR, A. (1995): Encountering Development: The Making and Unmaking of the Third World. Princeton University Press, Princeton, NJ.

FISCHER, F. (2003): Reframing Public Policy: Discursive Politics and Deliberative Practices. Oxford University Press, Oxford.

FISCHER, F. and FORESTER, J. (eds) (1993): The Argumentative Turn in Policy Analysis and Planning. Duke University Press, Durham, NC.

FOUCAULT, M. (1979): Discipline and Punish: The Birth of the Prison. Penguin Books, Harmondsworth.

FOUCAULT, M. (1988): Madness and Civilization: A History of Insanity in the Age of Reason. Vintage, New York.

FOX, N.J. (1998): 'Foucault, Foucauldians and sociology', British Journal of Sociology 49 (3): 415-433.

GAUSDAL KOMMUNE (2005): 'Om Gausdal' [WWW document]. Available at URL http://www.gausdal.kommune.no/ omkommunen/42210 [last accessed December 2007].

GLASER, B.G. and STRAUSS, A.L. (1967): The Discovery of Grounded Theory: Strategies for Qualitative Research. Aldine, New York.

GRIMSTAD, S. and SEVATDAL, H. (2007): Norwegian commons: history, status and challenges. Working Paper 40, Noragric, Norwegian University of Life Sciences, Ås.

GUNDERSEN, F. (1991): Den kommunale forvaltningen av viltog friluftsinteressene. Unpublished report, Department of Political Science, University of Oslo.

HAJER, M.A. (1995): The Politics of Environmental Discourse. Ecological Modernization and the Policy Process. Clarendon Press, Oxford

HOMPLAND, A. (1984): Rurbaniseringsprosessen: bygdebyen og det nye Norges ansikt. Working Paper 9/84, Institute for Social Research, Oslo.
HONGSLO, E. and BENJAMINSEN, T.A. (2002): 'Turning landscapes into "nothing": a narrative on land reform in $\mathrm{Na}$ mibia', Forum for Development Studies 29 (2): 321-347.

JASANOFF, S. (1990): The Fifth Branch: Science Advisers as Policymakers. Harvard University Press, Cambridge, MA.

LITFIN, K.T. (1994): Ozone Discourses: Science and Politics in Global Environmental Cooperation. Colombia University Press, New York.

LYOTARD, J.-F. (1997): The Postmodern Condition: A Report on Knowledge. University of Minnesota Press, Minneapolis, MN

MARTINEZ-ALIER, J. (2002): The Environmentalism of the Poor: A Study of Ecological Conflicts and Valuation. Elgar, Northampton, MA.

MCCARTHY, J. (2005): 'First World political ecology: directions and challenges', Environment and Planning A 37 (6): 953-958.

MILBOURNE, P. (1997): 'Hidden from view: poverty and marginalization in rural Britain', in MILBOURNE, P. (ed.): Revealing Rural 'Others': Representation, Power and Identity in the British Countryside. Pinter, London, pp. 89-116.

MJØSET, L. (2005): 'Can grounded theory solve the problems of its critics?', Sosiologisk Tidsskrift 13 (4): 379-408.

MJØSET, L. (2006): 'A case study of a case study: strategies of generalization and specification in the study of Israel as a single case', International Sociology 21 (5): 735-766.

MÜHLHÄUSLER, P. and PEACE, A. (2006): 'Environmental discourses', Annual Review of Anthropology 35: 457-479.

NEUMANN, I. (2006): 'Flerbent fellesskap i en norsk trekkhundklubb', Norsk antropologisk tidsskrift 17 (1): 48-59.

PEDERSEN, K. (1999): 'Det har bare vært naturlig'. Friluftsliv, kjønn og kulturelle brytninger. Unpublished Ph.D. dissertation. Norges idrettshøgskole, Oslo.

PEET, R. and WATTS, M. (1996): 'Liberation ecology: development, sustainability, and environment in an age of market triumphalism', in PEET, R. and WATTS, M. (eds): Liberation Ecologies: Environment, Development, Social Movements. Routledge, London, pp. 1-45.

PLOEG, J.D. VAN DER, RENTING, H., BRUNORI, G., KNICKEL, K., MANNION, J., MARSDEN,T., DE ROEST, K., SEVILLA-GUZMÁN, E. and VENTURA, F. (2000): 'Rural development: from practices and policies towards theory', Sociologia Ruralis 40 (4): 391-408.

ROBBINS, P. (2006): 'The politics of barstool biology: environmental knowledge and power in greater Northern Yellowstone', Geoforum 37 (2): 185-199.

ROE, E.M. (1991): 'Development narratives, or making the best of blueprint development', World Development 19 (4): 287-300.

ROE, E.M. (1995): 'Except-Africa: postscript to a special section on development narratives', World Development 23 (6): $1065-1069$.

ROE, E.M. (1999): Except-Africa, Remaking Development, Rethinking Power. Transaction Publishers, New Brunswick, NJ.

RØNNINGEN, K., ELDEN, K.M. and STRÆTE, E.P. (2001): Utmarka og lokal naringsutvikling. Sosiale og kulturelle forhold ved kommersialisering. Report 6/01, Centre for Rural Research, Norwegian University of Science and Technology, Trondheim.

RØNNINGEN, K. (2003): 'Bygdene mellom vern og kommersialisering', in HAUGEN, M.S. and STRÆTE, E.P. (eds): $U t$ $i$ verden og inn $i$ bygda. Festskrift til Reidar Almås. Tapir, Trondheim, pp. 97-108.

SALKIE, R. (1995): Text and Discourse Analysis. Routledge, London.

SCHROEDER, R.A., ST MARTIN, K. and ALBERT, K.E. (2006): 'Political ecology in North America: discovering the Third World within?', Geoforum 37 (2): 163-168. 
SKOGEN, K. (2001): 'Who's afraid of the big, bad wolf? Young people's responses to the conflicts over large carnivores in eastern Norway', Rural Sociology 66 (2): 203-220.

SKOGEN, K. and HAALAND, H. (2001): En ulvehistorie fra $\emptyset$ stfold. Samarbeid og konflikter mellom forvaltning, forskning og lokalbefolkning. NINA Fagrapport 52, Norwegain Instutute for Nature Research, Trondheim.

SKOGEN, K. and KRANGE, O (2003): 'A wolf at the gate: the anti-carnivore alliance and the symbolic construction of community', Sociologia Ruralis 43 (3): 309-325.

SKOGEN, K., HAALAND, H., KRANGE, O., BRAINERD, S.M. and HUSTAD, H. (2003): Lokale syn på rovvilt og rovviltforvaltning. En undersфkelse i fire kommuner: AurskogHoland, Lesja, Lierne og Porsanger. NINA Fagrapport 70, Norwegian Institute for Nature Research, Trondheim.

STOTT, P. and SULLIVAN, S. (eds) (2000): Political Ecology: Science, Myth and Power. Arnold, London.

STRAUSS, A.M. and CORBIN, J. (1990): Basics of Qualitative Research. Sage, Thousand Oaks, CA.

SVARSTAD, H. (2002): 'Analysing conservation-environment discourses: the story of a biopiracy narrative', Forum for Development Studies 29 (1): 63-92.

SVARSTAD, H. (2003): Rovviltkonflikter i noen europeiske land. NINA Fagrapport 68, Norwegian Institute for Nature Research, Trondheim.

SVARSTAD, H. (2004): 'A global political ecology of bio- prospecting', in PAULSON, S. and GEZON, L. (eds): Political Ecology Across Spaces, Scales and Social Groups. Rutgers University Press, New Brunswick, NJ, pp. 239-256.

SVARSTAD, H., PETERSEN, L.K., ROTHMAN, D., SIEPEL, H. and WÄTZOLD, F. (2008): 'Discursive biases of the environmental research framework DPSIR', Land Use Policy 25 (1): 116-125.

VIK, J. (2005): Trønderbonden. Typer og tilpasninger i trøndersk landbruk. Report 5/05, Centre for Rural Research, Norwegian University of Science and Technology, Trondheim.

VILLA, M. (2000): 'Rural life courses in Norway: living within the rural-urban complementarity', The History of Family 5 (5): 473-490.

VISTAD, O.I., DAUGSTAD, K. and SVARSTAD, H. (2006): 'Store verneområder med local forvaltning: Funn og refleksjonar'. Tidsskriftet Utmark 7(1) [WWW document]. URL http://www.utmark.org.

WAINWRIGHT, J. (2005): 'The geographies of political ecology: after Edward Said', Environment and Planning A 37 (6): 1033-1043.

WALKER, P.A. (2005): 'Political ecology: where is the ecology?', Progress in Human Geography 29 (1): 73-82.

WEBER, M. (1949): “"Objectivity” in social science and social policy', in The Methodology of the Social Sciences. Translated and edited by E.A. Shils and H.A. Finch. Free Press, Glencoe, IL. 